\title{
INFERIORITAS DAN KEPERCAYAAN DIRI PADA \\ PENYANDANG TUNA RUNGU
}

\author{
Suci fajar suryani \\ Falkutas Pskologi \\ Universitas Ahmad Dahlan yogyakarta \\ sucifajar09@gmail.com
}

\begin{abstract}
Abstrak
Penyandang tuna rungu dalam kehidupannya mengalami berbagai permasalahan yang kompleks diantaranya adalah mengenai inferioritas dan kepercayaan dirinya. Tujuan dari penulisan ini adalah untuk mengetahui bagaimananya inferioritas dan kepercayaan diri pada komunitas penyandang tuna rungu. Subjek penulisan ini adalah empat penyandang tuna rungu di komunitas " $X$ ". Pengumpulan data dengan metode wawancara dan observasi. Hasil menunjukan bahwa subjek merasa inferior dengan kecacatan yang dimilikinya. Subjek membutuhkan waktu yang cukup lama untuk menghilangkan perasaan inferiornya. Subjek secara bertahap berusaha menumbuhkan rasa percaya diri untuk mengatasi perasaan inferior yang dialami.
\end{abstract}

Kata kunci: inferioritas, kepercayaan diri, tuna rungu

\section{PENDAHULUAN}

Tuna rungu adalah salah satu bentuk kecacatan individu tidak mampu mendengar sehingga tidak dapat berkomunikasi secara lisan. Kecacatan dalam pendengaran menyebabkan penyandang tuna ru ngu tidak mampu memahami secara utuh suatu kejadian. Penyandang tuna rungu khususnya remaja dapat mengalami berbagai permasalahan yang kompleks terkait kecacatan yang dimiliki. Keterbatasan remaja yang mengalami tuna rungu ditunjukkan dengan ketidakmampuan dalam berkomunikasi sehingga dampaknya remaja tuna rungu menjadi terisolisasi atau merasa dikucilkan oleh lingkungan sosialnya dan kesulitan dalam beradaptasi dengan lingkungan sekitar. Selain itu kecacatan dapat berdampak pada rendahnya peneriman diri karena kecacatan yang dimilikinya yang menyebabkan hambatan pergaulan dalam masyarakat. Individu tidak dapat bersosialialisasi dengan masyarakat yang lebih luas (Tentama, 2012).

Remaja penyandang tuna rungu juga memiliki hak seperti anak normal lainnya. Namun Penyandang tuna rungu memiliki sikap inferioritas dan kepercayaan diri yang rendah karena kecacatannya. Menurut pemahaman umum, 
pengertian inferioritas itu adalah minder. Dalam kamus bahasa Indonesia, inferioritas itu diartikan dengan rasa rendah diri (Encyclopedia Britannica: 2006). Inferioritas menurut Adler adalah perasaan-perasaan yang muncul sebagai akibat kekurangan psikologis atau sosial yang di-rasakan secara subyektif merupakan perasaan-perasaan yang muncul dari kelemahan atau cacat tubuh nyata (Bischof, 1970). Artinya inferioritas bersumber dari rasa tidak lengkap maupun rasa tidak sempurna dalam setiap bidang kehidupan.walaupun orang yang tuna rungu ataupun cacat fisik memiliki rasa minder mereka juga memiliki rasa percaya diri bahwa mereka bisa melakukan halnya seperti orang normal lainnya.bahkan mereka terkadang lebih memiliki ekspresi kepercayaan diri yang tinggi dibandingkan dengan orang yang memiliki fisik sempurna. Mengapa bisa seperti itu? Karena mereka memiliki kemampuan yang membuat masyarakat terkagumkagum yang bahkan orang yang sering memandang mereka dengan sebelah mata. Hasil wawancara yang diperoleh dari data Deaf Art Community (DAC) bawasannya mereka memiliki rasa inferioritas ,tetapi rasa inferioritas ditutupi dengan rasa percaya dirinya karna penyandang tuna rungu bisa mengubah masyarakat yang memandang sebelah mata menjadi mengagumi nya.. Para ahli berkeyakinan bahwa kepercayaan diri bukanlah diperoleh secara instant, melainkan melalui proses yang berlangsung sejak usia dini, dalam kehidupan bersama orangtua. Meskipun banyak faktor yang mempengaruhi kepercayaan diri seseorang, namun faktor pola asuh dan interaksi di usia dini, merupakan faktor yang amat mendasar bagi pembentukan rasa percaya diri. Sikap orangtua, akan diterima oleh anak sesuai dengan persepsinya pada saat itu.

Berdasarkan uraian tersebut, penulis akan membahasan mengenai inferioritas dan penerimaan diri pada penyandang tuna rungu.

\section{PEMBAHASAN}

Rasa percaya diri adalah satu diantara aspek-aspek kepribadian yang penting dalam kehidupan manusia. Rasa percaya diri sangat membantu manusia dalam perkembangan kepribadiannya. Karena itulah rasa kepercayaan diri sangat dibutuhkan manusia dalam menjalani hidupnya.Inferioritas merupakan kebalikan 
dari superioritas (rasa percaya diri yang terlalu tinggi). Inferioritas itu adalah minder atau rasa rendah diri. Inferioritas adalah perasaan yang relatif tetap (persistent) tentang ketidakmampuan diri atau munculnya kecenderungan untuk merasa kurang atau menjadi kurang sehingga tidak bisa menunjukkan kebolehannya secara optimal , Rasa rendah diri tersebut harus dihilangkan karna dapat menghambat potensi yang dimiliki karna tidak bisa terekspolisasi (Tentama 2012)

Menurut Adler (Alwisol, 2009) menyatakan bahwa kebutuhan manusia yang paling penting adalah kebutuhan akan rasa percaya diri dan rasa superioritas. Menurut Hakim (2005) percaya diri adalah sebagai suatu keyakinan seseorang terhadap segala aspek kelebihan yang dimiliki dan keyakinan tersebut membuatnya merasa mampu untuk mencapai berbagai tujuan dalam hidupnya dan dapat menyesuaikan diri dengan lingkungannya.

Kepercayaan diri adalah keyakinan untuk melakukan sesuatu pada diri sebagai karakteristik pribadi yang mencakup keyakinan akan kemampuan diri, optimis, objektif, bertanggung jawab, rasional, dan realistis (Gufron \& Rini, 2014). Seseorang yang memiliki kepercayaan diri akan mampu mengenal dan memahami diri sendiri. Teori Lauster (2006), menjelaskan aspek-aspek kepercayaan diri sebagai berikut: Pertama, percaya pada kemampuan sendiri, yaitu keyakinan pada kemampuan diri sendiri dalam menghadapi dan mengatasi fenomena yang terjadi pada dirinya. Kedua, bertindak mandiri dalam mengambil keputusan, yaitu mampu mengambil keputusan sendiri tanpa adanya keterlibatan orang lain dan mampu menyakini tindakan yang diambil. Ketiga, memiliki rasa positif terhadap diri sendiri, dalam hal ini yang dimaksud adalah individu memiliki penilaian baik dari dalam diri sendiri, baik dari pandangan maupun tindakan yang dilakukan yang menimbulkan rasa positif terhadap diri dan masa depannya. Keempat, berani mengungkapkan pendapat, yaitu sikap mampu mengutarakan suatu dalam diri yang ingin diinginkan kepada orang lain tanpa adanya paksaan atau rasa yang dapat menghambart pengungkapan tersebut.

Perasaan-perasaan inferioritas pada beberapa orang penyebabnya adalah masalah-masalah fisik dan ada kebutuhan untuk mengkompensasinya. Ketika 
norma kesempurnaan dari super ego tidak dapat dipenuhi oleh ego inferioritas juga akan muncul (Semiun, 2006). Tidak jauh beda dari pendapat Semiun, Riyanto (2009) juga hampir sama dalam mengungkapkan arti dari inferioritas yaitu perasaan yang timbul jika kita tidak dapat mencapai keinginan untuk menuju superioritas.

Ketika individu memiliki perasaan inferior, maka mereka akan melaukan kompensasi sebagai usaha untuk mengatasi feeling of inferiority yang dimilikinya. Kompensasi yang biass dilakukan adalah membuat alasan, bersikap agresif, dan menarik diri. Selain itu pada umumnya akan menimbulkan suatu sikap dan perilaku peka (mrasa tidak senang) terhadap kritikan orang lain, sangat senang pujian penghargaan senang mengkritik atau mencela orang lain, kurang senang berkompetensi, dan cenderung menyendiri, pemalu, dan penakut (Yusuf, 2011).

\section{SIMPULAN}

Terkadang bukan hanya orang cacat fisik saja, yang memiliki sikap minder bahkan orang yang sehat jasmaninya pun memiliki sikap minder ,sikap minder seseorang mampu diatasi dengan memiliki rasa percaya diri yang besar dan motivasi yang kuat, sebagai contohnya Deaf Art Community (DAC), kelompok tersebut adalah kelompok tuna rungu yang memiliki tekat yang kuat untuk terus maju. Berdasarkan hasil observasi dan wawancara dengan keempat subjek, subjek sering minder tapi mereka mampu mengalahkan sikap keminderan mereka dengan cara punya tekat kepercayaan diri yang besar dan menghilangkan sifat keminderan mereka.

\section{DAFTAR PUSTAKA}

Al-uqshari, Y. (2001). Ats-tsiqatul binnafsi,kaifa tuqawwai tsiqataka binafsika ammaamal aakhariina.mesir: Daarul-lathaaif.

Chaplin, J. P. (2006). Kamus lengkap psikologi. Yogyakarta: Pustaka Pelajar Offset.

Ghufron \& Rini. (2010). Teori-teori psikologi. Yogyakarta: AR-RUZZ MEDIA. 
Hakim. T. (2005). Mengatasi rasa tidak percaya diri. Jakarta: Purwa Suara.

Yusnita, M. (2010). Kepercayaan diri individu Dwarfisme (Tinjauan Teori Psikologi Transpersonal). Tesis. tidak diterbitkan. Universitas Gunadarma.

Lestari, D. W. (2008). Pengaruh permainan tangga confidence terhadap peningkatan kepercayaan diri tuna rungu. Skripsi. Tidak di terbitkan.

Sarwono, S. W. (2002). Psikologi sosial. Jakarta: Balai Pustaka.

Semiun, Y. (2006). Teori kepribadian dan terapi psikoanalitik freud. Yogyakarta: Kanisius.

Tentama, F. (2012). Mengatasi inferioritas difabel. Harian Jogja.

Tentama, F. (2012). Mencari sisi penerimaan diri difabel. Harian Jogja, 1367.

Riyanto, T., \& Heru S. (2009). Mau bahagia?. Yogyakarta: Kanisius.

Yusuf, S. (2011). Mental hygiene: Terapi psiko-spiritual untuk hidup sehat berkualitas. Bandung: Maestro. 